JSAP: Journal Syariah and Accounting Public

ISSN: 2622-3538

Available Online at https://journal.umgo.ac.id/index.php/JSAP/index

Vol. 3, No. 2 Desember 2020

DOI: $10.31314 /$ jsap.3.2.59-65.2020

\title{
PENGARUH KOMPETENSI APARAT DESA DAN TINGKAT PENDIDIKAN TERHADAP AKUNTABILITAS PENGELOLAAN DANA DESA (Studi Pada Aparat Desa Se Kecamatan Walea Besar Kabupaten Tojo Una-Una)
}

\author{
Mattoasi $^{1}$, Aston Sapeni ${ }^{2}$, Didiet Pratama Musue ${ }^{3}$ \\ 1,2,3 . Program Studi Jurusan Akuntansi, Universitas Negeri Gorontalo Indonesia, \\ Email; mattosuming@gmail.com
}

Info Artikel: Diterima: 13 Oktober 2020, Disetujui: 23 November 2020, Publish 15 Desember 2020

\begin{abstract}
:
This study aims to determine the effect of the competence of village officials and education and training simultaneously on the accountability of village fund financial management by the Village Government in Walea Besar District, Tojo Una-Una Regency partially or simultaneously. This research is a quantitative study. The population in the study was 113 village officials, then the sampling method was purposive sampling so that the sample in the study was 39 people. The results of this study indicate that the competence of village officials and the education and training of village officials partially or simultaneously have a significant effect on the accountability of village fund management in the village of Walea Besar District, Tojo Una-Una Regency. The value of Ajusted $R$ Square is 0.622 . This value shows that $62.2 \%$ of the variability of village fund management accountability in the Village in Walea Besar District, Tojo Una-Una Regency can be explained by the competence of village officials and education and training of village officials, while the remaining $37.8 \%$ can be explained by other variables. which were not examined in this study were the variables of the role of the village head and the awareness of the apparatus.
\end{abstract}

Keywords: Apparatus Competence, Education and Training, Accountability

\section{Abstrak:}

Penelitian ini bertujuan untuk mengetahui pengaruh dari kompetensi aparat desa dan pendidikan dan pelatihan secara simultan terhadap Akuntabilitas pengelolaan keuangan dana desa oleh Pemerintah Desa se Kecamatan Walea Besar Kabupaten Tojo Una- Una secara parsial maupun simultan. Penelitian ini merupakan penelitian kuantitatif. Populasi dalam penelitian 113 aparat desa kemudian metode pengambilan sampel yakni purposive sampling sehingga sampel dalam penelitian sebanyak 39 orang. Hasil penelitian ini menunjukan bahwa Kompetensi aparat desa dan pendidikan dan pelatihan aparat desa secara parsial maupun simultan berpengaruh signifikan terhadap akuntabilitas pengelolaan dana desa pada Desa di Kecamatan Walea Besar Kabupaten Tojo Una-Una. Nilai Ajusted R Square sebesar 0,622. Nilai ini menunjukan bahwa sebesar $62,2 \%$ variabilitas akuntabilitas pengelolaan dana desa pada Desa di Kecamatan Walea Besar Kabupaten Tojo Una-Una dapat dijelaskan oleh kompetensi aparat desa dan pendidikan dan pelatihan aparat desa, sedangkan sisanya sebesar $37,8 \%$ dapat dijelaskan oleh variabel lain yang tidak diteliti dalam penelitian ini seperti variabel peran kepala desa dan kesadaran aparat.

Kata kunci : Kompetensi Aparat, Pendidikan dan Pelatihan, Akuntabilitas 


\section{PENDAHULUAN}

Sebelum adanya UU no. 6 tahun 2014 tentang dana Desa, Desa sering identik dengan kemiskinan dan ketertinggalan karena selama ini desa kurang mendapat perhatian oleh Pemerintah Pusat sehingga terdapat ketimpangan yang jelas antara masyarakat desa dengan masyarakat kota sehingga secara bertahap pemerintah mulai mungucurkan dana desa karena tanpa adanya aktivitas pendanaan maka desa akan kesulitan dalam menjalankan pelaksanaan dan pemberdayaan masyarakat desa secara baik (Purba, 2020). Sehubungan dengan Dana Desa, menurut Pahlawan, Wijayanti, dan Suhendro (2020) dan Indraswari dan Rahayu (2021) Salah satu tugas aparatur desa yaitu untuk mengelola dana desa yang disalurkan oleh pemerintah pusat kepada pemerintah desa guna pembangunan desa dengan prinsip pengelolaan yang baik, transparan dan akuntabel. Demikian juga dengan pendapat Dewi dan Gayatri (2019); Susanti (2021); Purba (2020); dan Widiyanti (2017) yang menyatakan bahwa akuntabilitas menjadi tolak ukur bagi aparatur desa atas tanggungjawab dalam pekerjaan mereka sehingga pada akhir kegiatan penyelenggaraan pemerintahan desa harus dapat mempertanggungjawabkan kepada masyarakat desa sesuai dengan ketentuan. Akuntabilitas sangat diperlukan oleh seluruh Masyarakat Desa tidak terkecuali pada Kecamatan Walea Besar Kabupaten Tojo Una-una. Di Kecamatan tersebut masih banyak Aparat Desa yang belum maksimal melakukan pertanggungjawaban ke Masyarakat.

Berhubungan dengan permasalahan sebelumnya mengenai akuntabilitas pengelolaan dana desa maka Peneliti mencari variabel-variabel yang dapat mempengaruhi pengelolaan dana Desa.
Salah satu yang dapat mempengaruhinya menurut Pahlawan, Wijayanti, dan Suhendro (2020); Zulkifli, Sandrayati, dan Ariani (2021); dan Atiningsih dan Ningtyas (2019) menyatakan bahwa perlu adanya dukungan dari aparatur Desa yang berkompeten dalam mengelola keuangan Desa. Sehingga dengan adanya Aparatur desa yang berkompeten dapat mengurangi penyimpangan yang mungkin muncul dalam pengelolaan dana desa (Pahlawan, Wijayanti, dan Suhendro, 2020). Tidak jauh berbeda dengan pendapat sebelumnya Menurut Zulkifli, Sandrayati, dan Ariani (2021); dan Umaira dan Adnan (2019) bahwa kompetensi aparatur desa yang baik merupakan bagian yang penting dalam proses pengelolaan dana desa dan kegiatan pemerintah lainnya dimana setiap aparatur desa memiliki komitmen yang tinggi untuk melaksanakan pengelolaan dengan sebaikbaiknya, dan bertanggung jawab.

Terwujudnya akuntabilitas dalam rangka peningkatan kualitas kinerja pemerintahan desa

sehingga pengelolaan dana desa menjadi tolak ukur kepercayaan masyarakat terhadap pengelolaan dana desa. Kepercayaan inilah yang akan mengurangi tingkat penyimpangan dana desa sehingga masyarakat desa dapat diberdayakan menjadi masyarakat mandiri dan pada akhirnya menjadi desa mandiri (Arfiansyah, 2020). Penelitian terkait Kompetensi Aparat desa pernah diteliti oleh Pahlawan, Wijayanti, dan Suhendro (2020); Zulkifli, Sandrayati, dan Ariani (2021); dan Atiningsih dan Ningtyas (2019) yang menyatakan bahwa Kompetensi Aparat Desa berpengaruh positif terhadap pengelolaan Dana Desa.

Selain Kompetensi Aparat desa kemungkinan yang mempengaruhi pengelolaan dana Desa yaitu pendidikan 
yang diperoleh aparatur Desa. Pendapat tersebut sejalan dengan Siallagan (2020); dan Irnanta (2020) yang menyatakan bahwa tingkat Pendidikan penting karena mereka nantinya akan melaksanakan dan membentuk laporan keuangan yang akuntabel dan berkualitas, dengan demikian dalam hal ini SDM harus menjadi perhatian penting bagi setiap pemerintah desa. Dalam penelitian Siallagan (2020); dan Irnanta (2020) pendidikan berpengaruh positif.

\section{METODE PENELITIAN}

Lokasi yang dijadikan sebagai obyek penelitian adalah Pemerintah Desa se Kecamatan Walea Besar Kabupaten Tojo Una-Una. Penelitian ini akan dilaksanakan selama \pm 6 dari bulan April 2018 hingga September 2018. Populasi dalam penelitian ini yakni seluruh aparat desa se Kecamatan Walea Besar Kabupaten Tojo Una-Una sebanyak 113 orang. Dengan menggunakan purposive sampling, diperoleh jumlah sampel sebanyak 39 orang.

Untuk menjawab hipotesis maka peneliti melakukan uji validitas dan reliabilitas terhadap variabel Kompetensi Aparat Desa (X1), Variabel Tingkat Pendidikan (X2), dan Variabel Akuntabilitas Pengelolaan Dana Desa (Y). Hasil dari validitas dan reliabilitas dilanjutkan dengan analisis regresi sederhana dengan melihat pengaruh diantara 2 Variabel. Keadaan ini sesuai dengan kehendah Creswell (2016) dan Sugiono (2018) bahwa analisis kausal dapat digunakan untuk mengetahui pengaruh terhadap suatu variabel dengan variabel yang lain. Berdasarkan uraian yang telah dikemukakan, maka desain penelitian dalam penelitian ini yang dibuat berdasarkan beberapa teori dan konsep kinerja pemerintah daerah yang dianggap bahwa sangat menentukan kinerja pemeriuntah daerah.

\section{HASIL DAN PEMBAHASAN}

\section{Akuntabilitas}

Menurut Peraturan Pemerintah No.71 Tahun 2010 tentang Standar Akuntansi Pemerintah Akuntabilitas adalah mempertanggungjawabkan pengelolaan sumber daya serta pelaksanaan kebijakan yang dipercayakan kepada entitas pelaporan dalam mencapai tujuan yang telah ditetapkan secara periodik. Pendapat tersebut sejalan dengan Purba (2020) yang menyatakan bahwa akuntabilitas merupakan suatu kewajiban dari pemegang amanah atau didalam pemerintahan desa disebut kepala desa dan aparatnya untuk memberikan pertanggung jawaban, menyajikan, melaporkan dan mengungkapkan segala sesuatu aktivitas dan kegiatan yang menjadi tanggung jawabnya kepada pihak pemberi amanah yang memiliki hak dan kewenangan untuk meminta pertanggungjawaban tersebut. Tidak jauh berbeda dengan Pendapat sebelumnya Noordiawan, (2006:34) menyatakan bahwa Akuntabilitas merupakan suatu proses yang dilakukan untuk mempertanggungjawabkan pengelolaan sumber daya atau dana desa yang diperoleh dari pemerintah pusat serta pelaksanaan kebijakan yang dipercayakan kepada aparatur desa dalam mencapai tujuan yang telah ditetapkan secara periodik.

\section{Kompetensi Aparat Desa}

Menurut Undang-Undang

Ketenagakerjaan Nomor 13 Tahun 2013 
menyatakan bahwa kompetensi kerja merupakan kemampuan kinerja setiap individu yang mencakup aspek pengetahuan, keterampilan dan sikap kerja yang sesuai dengan standar yang telah ditetapkan. Hal ini sejalan dengan Havesi (2005) yang menyatakan bahwa kompetensi merupakan suatu karakteristik dari seseorang yang memiliki keterampilan (skill), pengetahuan (knowledge), dan kemampuan (ability) untuk melaksanakan suatu pekerjaan. Tidak jauh berbeda dari Pendapat sebelumnya menurut Iraswati dan Rahayu (2021) kompetensi kerja merupakan kemampuan seseorang dalam aspek pengetahuan, keterampilan dan sikap kerja yang diperoleh melalui proses pendidikan, pelatihan ataupun pengalaman.

\section{Pendidikan}

Menurut Siallagan (2020) Pendidikan merupakan satu cara yang mampu meningkatkan ilmu pengetahuan, keterampilan maupun keahlian guna menunjang kinerja pegawai tentunya akan bermuara pada hasil kerja yang berkualitas seperti penyusunan laporan keuangan yang akan semakin baik. Dengan adanya pendidikan maka tingkat pemahaman dan pekerjaan sumber daya

manusia mengenai laporan dana desa akan lebih mudah terlaksana dan tepat waktu sesuai dengan batas waktu pelaporan yang ditentukan (Irnanta, 2020).

\section{Hasil Penelitian}

\section{Kompetensi Aparat Desa}

Penelitian kuantitatif ini memiliki tujuan untuk mengetahui pengaruh dari variabel kompetensi aparat desa dan tingkat Skor variabel kompetensi aparat desa yakni sebesar sebesar $71,11 \%$ yang berada pada kategori yang "cukup baik". Hal ini menunjukan bahwa kompetensi aparat desa oleh Desa di Kecamatan Walea Besar
Kabupaten Tojo Una-Una sudah mulai bagus namun masih perlu ditingkatkan melalui pendidikan dan pelatihan yang lebih intens kepada aparat desa agar mampu dalam menjalankan amanah dan tanggung jawabnya dalam pengelolaan dana desa. Adanya kompetensi yang baik tentu akan membuat pengelolaan keuangan menjadi lebih akuntabel sehingga penerimaan dan pengeluaran secara rinci dan jelas dapat dipertanggungjawabkan oleh aparat desa.

\section{Variabel Tingkat Pendidikan Aparat}

\section{Desa}

Tingkat pendidikan aparat desa terletak pada kriteria yang "cukup baik" dengan persentase skor sebesar $76,41 \%$. Hal ini menunjukan bahwa aparat desa di desa di Kecamatan Walea Besar Kabupaten Tojo Una-Una memiliki jenjang pendidikan yang sesuai dengan persyaratan dalam menduduki posisi dalam pemerintahan desa namun demikian masih perlunya perhatian dan pembenahan terutama dalam pendidikan non formal dan informal agar lebih relevan dengan posisi pekerjaan dimana terdapat banyak aparat desa yang menduduki bagian pengelolaan keuangan namun dalam pelatihan dan pendidikan yang dilakukan oleh pemerintah daerah masih kurang perhatiannya akan hal tersebut.

\section{Variabel Akuntabilitas Pengelolaan Dana Desa}

Skor untuk variabel akuntabilitas pengelolaan dana desa pada Desa di Kecamatan Walea Besar Kabupaten Tojo Una-Una yakni sebesar $77,52 \%$ yang terletak pada kriteria yang "cukup baik". Hal ini menunjukan bahwa aparat desa di Kecamatan Walea Besar Kabupaten Tojo Una-Una mampu untuk mempertanggung jawabkan berbagai penerimaan dan pengeluaran dana desa yang dikelola. Dengan adanya akuntabilitas pengelolaan keuangan ini maka akan memiliki dampak 
berkualitasnya pentausahaan dan transparansi pengelolaan dana desa yang kemudian hal ini akan menjadi progres baik bagi peningkatan kucuran dana desa di . desa-desa Kecamatan Walea Besar Kabupaten Tojo Una-Una.

Hasil analisis data merupakan gambaran mengenai hasil pengujian hipotesis, persamaan regresi hingga koefisien determinasi. Hasil pengujiannya dapat disajikan berikut ini:

Tabel 2: Hasil Analisis Regresi

Berganda

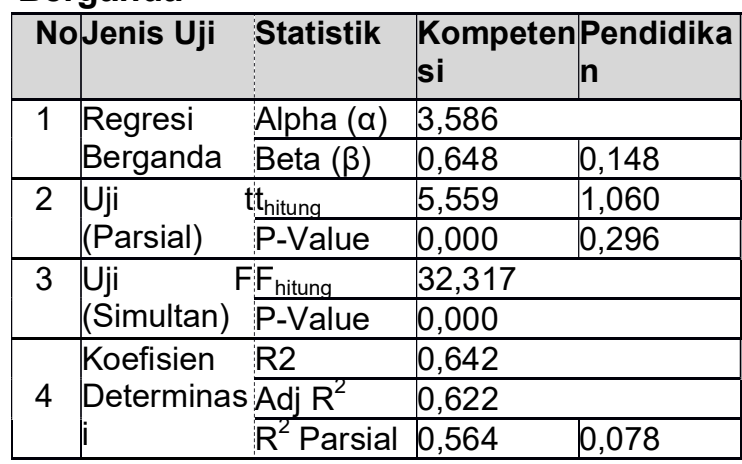

Sumber data diolah 2021

Berdasarkan tabel di atas maka dapat dijabarkan hasil pengujian hipotesis, persamaan regresi hingga koefisien determinasi:

\section{Hasil Analisis Regresi Berganda}

Analisis regresi Berganda digunakan untuk melihat pengaruh beberapa variabel bebas terhadap variabel terikat. Setelah dilakukan uji asumsi klasik dan ternyata dipenuhi, tahap selanjutnya dilakukan pemodelan data dengan menggunakan analisis regresi berganda. Berdasarkan hasil analisis pada tabel 2, maka model regresi linear berganda yang dibangun adalah:

$$
\hat{Y}=3,586+0,648 X_{1}+0,148 X_{2}+e
$$

\section{Hasil Uji Parsial}

Hasil pengujian pengaruh setiap variabel bebas terhadap variabel terikat adalah sebagai berikut:

1) Pengaruh kompetensi aparat desa Terhadap akuntabilitas pengelolaan dana desa
Nilai $t_{\text {hitung }}$ untuk variabel kompetensi aparat desa sebesar 5,559 lebih besar dari nilai $t_{\text {tabel }}$ yang sebesar 2,028. Kemudian koefisien dari regresi untuk pengujian hipotesis pertama yakni positif. Nilai t positif menunjukkan bahwa adanya hubungan yang searah antara kompetensi aparat desa dengan akuntabilitas pengelolaan dana desa Desa di Kecamatan Walea Besar Kabupaten Tojo Una-Una

\section{2) Pengaruh tingkat pendidikan aparat desa Terhadap akuntabilitas pengelolaan dana desa \\ Tingkat pendidikan aparat desa} berpengaruh positif tidak signifikan terhadap akuntabilitas pengelolaan dana desa pada Desa di Kecamatan Walea Besar Kabupaten Tojo Una-Una. Hal tersebut karena nilai $t_{\text {hitung }}$ untuk variabel tingkat pendidikan aparat desa sebesar 1,060 lebih kecil dari nilai $t_{\text {tabel }}$ yang sebesar 2,028. Nilai $t$ positif menunjukkan bahwa adanya hubungan yang searah antara tingkat pendidikan aparat desa dengan akuntabilitas pengelolaan dana desa pada Desa di Kecamatan Walea Besar Kabupaten Tojo Una-Una

\section{Hasil Pengujian Simultan (Uji F)}

Nilai $F_{\text {hitung penelitian ini sebesar }}$ 32,317. $F_{\text {tabel }}$ pada tingkat signifikansi $5 \%$ dan df1 sebesar $\mathrm{k}=2$ dan df2 sebesar N-k$1=39-2-1=36$ adalah sebesar 3,259. Nilai Fhitung yang diperoleh jauh lebih besar $F_{\text {tabel }}$ sehingga $\mathrm{Ho}$ ditolak dan $\mathrm{H} 1$ diterima. Artinya kompetensi aparat desa dan tingkat pendidikan aparat desa secara bersamasama berpengaruh signifikan terhadap akuntabilitas pengelolaan dana desa pada Desa di Kecamatan Walea Besar Kabupaten Tojo Una-Una.

\section{Koefisien Determinasi}

Hasil Ajusted R Square sebesar 0,622. Nilai ini menunjukan bahwa sebesar $62,2 \%$ variabilitas akuntabilitas pengelolaan dana desa pada Desa di 
Kecamatan Walea Besar Kabupaten Tojo Una-Una dapat dijelaskan oleh kompetensi aparat desa dan tingkat pendidikan aparat desa, sedangkan sisanya sebesar $37,8 \%$ dapat dijelaskan oleh variabel lain yang tidak diteliti dalam penelitian ini seperti variabel peran kepala desa dan kesadaran aparat desa.Selain itu, penmgujian dapat pula dilakukan dengan melihat hasil pengujian koefisien determinasi secara parsial yang hasilnya bahwa (1) koefisien determinasi pasrial variabel kompetensi aparat desa sebesar 0,564 atau dalam hal ini sebesar $56,4 \%$ variabilitas akuntabilitas pengelolaan dana desa pada Desa di Kecamatan Walea Besar Kabupaten Tojo Una-Una dapat dijelaskan oleh kompetensi aparat desa. (2) nilai koefisien determinasi pasrial variabel tingkat pendidikan aparat desa sebesar 0,078 atau dalam hal ini sebesar $7,8 \%$ variabilitas akuntabilitas pengelolaan dana desa pada Desa di Kecamatan Walea Besar Kabupaten Tojo Una-Una dapat dijelaskan oleh tingkat pendidikan aparat desa.

\section{KESIMPULAN}

Berdasarkan hasil penelitian dan pembahasan di atas, maka dapat ditarik beberapa simpulan sebagai berikut:

1. Kompetensi aparat desa berpengaruh positif dan signifikan terhadap akuntabilitas pengelolaan dana desa pada Desa di Kecamatan Walea Besar Kabupaten Tojo Una-Una. Nilai t positif menunjukkan bahwa adanya hubungan yang searah antara kompetensi aparat desa dengan akuntabilitas pengelolaan dana desa di Kecamatan Walea Besar Kabupaten Tojo Una-Una

2. Tingkat pendidikan aparat desa berpengaruh positif tidak signifikan terhadap akuntabilitas pengelolaan dana desa pada Desa di Kecamatan Walea Besar Kabupaten Tojo Una-Una. Nilai $t$ positif menunjukkan bahwa adanya hubungan yang searah antara tingkat pendidikan aparat desa dengan akuntabilitas pengelolaan dana desa di Kecamatan Walea Besar Kabupaten Tojo Una-Una

3. Kompetensi aparat desa dan tingkat pendidikan aparat desa secara bersama- sama berpengaruh signifikan terhadap akuntabilitas pengelolaan dana desa di Kecamatan Walea Besar Kabupaten Tojo Una-Una. Nilai Ajusted $R$ Square sebesar 0,622 menunjukan bahwa sebesar $62,2 \%$ variabilitas akuntabilitas pengelolaan dana desa dapat dijelaskan oleh kompetensi aparat desa dan tingkat pendidikan aparat desa, sedangkan sisanya dijelaskan oleh variabel lain yang tidak diteliti dalam penelitian ini seperti variabel peran kepala desa dan kesadaran aparat desa.

\section{REFERENSI}

Arfiansyah, M.A. 2020. Dampak Dana Desa Dalam Penanggulangan Kemiskinan di Jaw Tengah. Jurnal Lisyabab, Vol. 1 No. 1, Juni 2020, hlm. 91-106.

Atiningsih, S., \& Ningtyas, A. C. (2019). Pengaruh kompetensi aparatur pengelola dana desa, partisipasi masyarakat dan sistem pengendalian internal terhadap akuntabilitas pengelolaan dana desa. Jurnal IImu Manajemen dan Akuntansi Terapan, 10(1), 14-25.

Dewi, N. K., \& Gayatri. (2019). Faktor-faktor yang berpengaruh pada akuntabilitas pengelolaan dana desa. E-Jurnal Akuntansi Universitas Udayana, 26(2), 1269-1298.

Hevesi, G. Alan. 2005. Standards for Internal Control in New York State Government. 
Indraswari, N. E., \& Rahayu, Y. (2021). Pengaruh Kompetensi Pemerintah Desa, Partisipasi Masyarakat Dan Pemanfaatan Teknologi Informasi Terhadap Akuntabilitas Pengelolaan Dana Desa. Jurnal IImu dan Riset Akuntansi (JIRA), 10(4).

Irnanta, H. (2020). Analisis Pengaruh Pendidikan dan Pelatihan Terhadap Peningkatan Kualitas Akuntabilitas Keuangan Desa. Jurnal IImiah Ecobuss, 8(1), 1-8.

Noordiawan. (2006). Akuntansi sektor publik. Jakarta: Salemba Empat.

Pahlawan, E. W., Wijayanti, A., \& Suhendro, S. (2020). Pengaruh kompetensi aparatur desa, sistem pengendalian internal, pemanfaatan teknologi informasi dan partisipasi masyarakat terhadap akuntabilitas pengelolaan dana desa. Indonesia Accounting Journal, 2(2), 162-172.

Peraturan Pemerintah Republik Indonesia No.71 Tahun 2010 tentang Standar Akuntansi

Purba, S. (2020). Pengaruh pemahaman dan peran perangkat desa terhadap akuntabilitas pengelolaan dana desa (Studi Kasus Pada Desa di Kecamatan Pinangsori Kabupaten Tapanuli Tengah). JAKK| Jurnal Akuntansi dan Keuangan Kontemporer, 3(1), 10-19.

Siallagan, H. (2020). Pengaruh pendidikan dan pelatihan, pemanfaatan teknologi dan kompetensibidang akuntansi terhadap kualitas laporan keuangan. Akuntabilitas, 14(2), 211224.
Susanti, S. (2021, Juli). Pengaruh Kompetensi Sumber Daya Manusia, Pendampingan Kampung dan Pemantauan terhadap Akuntabilitas Pengelolaan Keuangan Kampung di Kabupaten Siak Provinsi Riau. In Prosiding Seminar Nasional Ekonomi, Bisnis \& Akuntansi (Vol. 1, pp. 79-86).

Umaira, S. dan Adnan. 2019. Pengaruh Partisipasi Masyarakat, Kompetensi Sumber Daya Manusia, dan Pengawasan Terhadap Akuntabilitas Pengelolaan Dana Desa (Studi Kasus pada Kabupaten Aceh Barat Daya). Jurnal IImiah Mahasiswa Ekonomi Akuntansi 4(3):471-481.

Universitas Syiah Kuala.

Undang-Undang Ketenagakerjaan Nomor 13 Tahun 2013

Undang-Undang no. 6 tahun 2014 tentang dana Desa

Widiyanti, A. (2017). Akuntabilitas dan transparansi pengelolaan alokasi dana desa: Studi Pada Desa Sumberejo Dan Desa Kandung Di Kecamatan Winongan Kabupaten Pasuruan (Doctoral dissertation, Universitas Islam Negeri Maulana Malik Ibrahim).

Zulkifl, Z., Sandrayati, S., \& Ariani, N. (2021). Pengaruh kompetensi aparatur desa, sistem pengendalian internal dan komitmen organisasi terhadap akuntabilitas pengelolaan dana desa di kecamatan muara enim kabupaten muara enim. JEMBATAN (Jurnal Ekonomi, Manajemen, Bisnis, Auditing, dan Akuntansi), 6(1), 26-38. 